VEILED DESIRES 
This page intentionally left blank 


\section{MAUREEN SABINE}

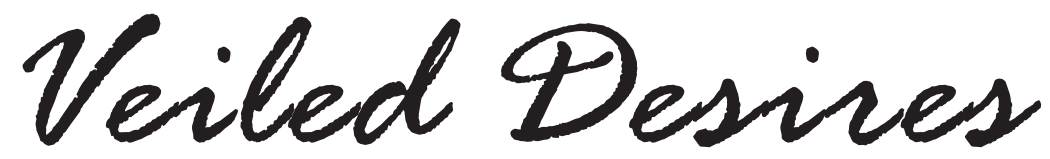

INTIMATE PORTRAYALS

OF NUNS IN POSTWAR

ANGLO-AMERICAN FILM

F ORDHAM UN IVERS I T PRESS

New York / 2013 


\section{Copyright (C) 2013 Fordham University Press}

All rights reserved. No part of this publication may be reproduced, stored in a retrieval system, or transmitted in any form or by any means-electronic, mechanical, photocopy, recording, or any other-except for brief quotations in printed reviews, without the prior permission of the publisher.

Fordham University Press has no responsibility for the persistence or accuracy of URLs for external or third-party Internet websites referred to in this publication and does not guarantee that any content on such websites is, or will remain, accurate or appropriate.

Fordham University Press also publishes its books in a variety of electronic formats. Some content that appears in print may not be available in electronic books.

Library of Congress Cataloging-in-Publication Data

Sabine, Maureen.

Veiled desires : intimate portrayals of nuns in postwar Anglo-American film / Maureen Sabine. - First edition.

pages $\mathrm{cm}$

Includes bibliographical references and index.

ISBN 978-0-8232-5I65-0 (cloth : alk. paper) — ISBN 978-0-8232-5I66-7

(pbk. : alk. paper)

I. Nuns in motion pictures. 2. Motion pictures-Great Britain-History. 3.

Motion pictures-United States-History. I.Title.

PNi995.9.N95S23 2013

79I.43094I-dc23

2012050170

Printed in the United States of America

I5 I4 I3 5432 I

First edition 
To Martin, for his staunch love, constancy, and faith, and to Chris, Peter, and Tony, who make our circle complete.

"Thy firmnes makes my circle just, And makes me end, where I begunne."

John Donne, "A Valediction forbidding mourning" 
This page intentionally left blank 